\title{
Centralization of University Library Services: Some Compelling Factors in Nigerian Universities
}

\begin{abstract}
In Nigerian universities certain patterns of library service have emerged which are neither ideal nor in the best interest of users and library staff. The most effective way of improving these patterns is by centralizing operations in these libraries. Insufficient funds, the need for planned growth, necessity for a union catalog at local and national levels, and effective deployment of library staff are compelling factors for such centralization.
\end{abstract}

I

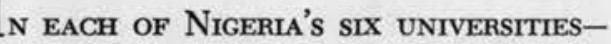
Ibadan, Nigeria (Nsukka), Ahmadu Bello, Ife, Lagos, and Benin-there are a variety of libraries, ranging from the main library to small departmental reading rooms. Departmental reading rooms as they now exist cannot be called libraries, since in most cases they are unorganized and are developed by the departments for reference purposes and as supplementary collections to the main library collection. Only the main libraries and faculty, school, institute, and college libraries come within the scope of this study.

Rather than discussing centralization versus decentralization, this paper focuses on those factors that make it imperative for university libraries to incorporate a certain degree of centralization in their development. As M. F. Tauber points out, centralization conveys different meanings depending upon the adjective used with it-administra-

Mr. Adediran is acquisitions librarian, Ibadan University Library, Ibadan, Nigeria. tive, physical, or operational centralization. ${ }^{1}$ In this article centralization has an operational slant, so that certain functions like administration and technical services, if centralized, would be performed in the same place by the same personnel for the various units of a system.

At the University of Ibadan, only the medical library is directly controlled by the main library. Others are autonomous with the main library playing solely an advisory role in their development. There is most complete centralization at the University of Nigeria, Nsukka, where all the institute and faculty libraries are controlled by the main library. Each of the libraries at Ahmadu Bello University is autonomous in conducting its business. At the University of Ife, although the official policy states that all libraries are under the jurisdiction of the university librarian, in practice this is not so; the other three libraries are independent of the main library. The University of Lagos has two college libraries apart from the main library, and these are virtually autono- 
mous. The University of Benin is a relatively young institution with only a main library. The number of libraries in each university, their staff strength, and 1972-73 budgets are shown in Table 1.

With the exception of the University of Nigeria, Nsukka, other libraries within the universities operate independently of the main libraries. The hiring of staff, development and processing of stock, services to readers, etc., are virtually left to the various faculties or schools, institutes, and colleges.

In a few cases independent libraries are lucky to be manned by professional librarians, but even then the performance of the librarians is subject to the interest shown by the deans or heads. Because no performance standards are set for these libraries, the whims and caprices of the deans or heads set the norms. At the University of Ibadan, an attempt has been made by the main library to establish standards for the other libraries, but it lacks the statutory power to enforce them. It plays an advisory role only.

Such a loose relationship is not ideal for effective library service. Lack of effective control in the development of libraries within the universities leads to duplication of stock, as one library does not know what the other has. It is also responsible for the general nonexistence of union catalogs-a crucial need for developing resource sharing among these libraries. The lack of qualified personnel to staff these libraries is no longer as serious as it used to be, but the staff situation is still not entirely satisfactory, especially in the newer universities. There is, however, a need for effective deployment of available human resources.

Four factors, particularly, make operational centralization a sine qua non of library organization in Nigerian universities: (1) insufficient funds, (2) need for planned growth, (3) need for interlibrary cooperation, and (4) effective deployment of library staff.

\section{INSUFFICIENT FUNDS}

Dipeolu mentions this factor when he writes: "Where money and staff are scarce, one cannot afford to decentralize in the European manner. Even when some of the conditions that call for departmentalization apply, all technical activities should be centralized whilst assistance to readers might be given in the sectional libraries."2 In view of the limited financial resources of most of these universities, it is essential that duplication of stock and services, which invariably increases cost, should be eliminated as much as possible. Rather than allow the various libraries in each university to do their own ordering, processing, binding of journals, and repairs to damaged books, centralization would reduce

TABLE 1

Staff Strength AND Budget of Nigeruan UNIVERSITY LIBRARIES $1972-73^{\circ}$

\begin{tabular}{lcccl}
\hline \hline & $\begin{array}{c}\text { Libraries in } \\
\text { the System }\end{array}$ & $\begin{array}{c}\text { Professional } \\
\text { Librarians }\end{array}$ & $\begin{array}{c}\text { Budget } \\
\text { (Books and Periodicals) }\end{array}$ & \multicolumn{1}{c}{$\begin{array}{c}\text { Union } \\
\text { Catalog }\end{array}$} \\
\hline Ibadan & 6 & 30 & $\$ 173,598$ & None \\
Nsukka & 7 & 19 & 223,998 & Yes (but not comprehensive) \\
Ahmadu Bello & 6 & 24 & 133,000 & None \\
Ife & 4 & 15 & 157,400 & None \\
Lagos & 3 & 25 & 200,189 & None \\
Benin & 1 & 8 & 98,000 & Not applicable \\
\hline
\end{tabular}

- Information obtained from questionnaires sent to the various libraries and the latest university calendars and library annual reports. 
operational costs. The money thus saved could be usefully spent for buying multiple copies of titles for student use. This is a particularly important aspect of service to readers in Nigeria, for many students cannot afford to buy basic texts; and added to this is the problem of the rising prices of books.

\section{Need for Planned Growth}

This need arises from the currently uncontrolled pattern governing the establishment and growth of libraries in most Nigerian universities. As noted above, the relationship among main libraries and other libraries is, in most cases, advisory. This allows the various libraries to evolve their own types of service, however unsatisfactory. If planned growth for these libraries is to be achieved, the main libraries must be in a position to formulate standards and be statutorily empowered to enforce them. This is a sound basis for operational centralization. The University of Nigeria library system operates in this way:

The University of Nigeria consists of the Nnamdi Azikiwe Library and the Economic Development Institute Library also located at the Enugu Campus, together with small collections in the Agriculture and Education Faculties on the Nsukka Campus. All the collections are serviced from the Nnamdi Azikiwe Library which is the main library where the union catalogue is housed. ${ }^{3}$

\section{NeEd for a Union Catalog}

The only way to utilize fully the library resources in each university is for the main library to maintain a union catalog of all materials held in the various libraries. This can be achieved with proper directives from the main library concerning procedures for sending in cards on the holdings of all the other libraries, uniform catalog entry patterns, and the general adoption of a classification scheme. At the moment, much time and effort is wasted in trying to ascertain the holdings of each library, because union catalogs generally do not exist. Union catalogs provide the basis for speedy and efficient resource sharing-a cooperative venture much needed in Nigeria. This is a particularly important issue, because no library in the world (let alone in Nigeria) can be self-sufficient.

\section{EFfective Deployment of StafF}

Within a centralized system, it is possible to deploy library staff in the most effective way. This can be achieved by deploying staff along subject lines in the main library as well as in other libraries (which invariably cater to a particular subject interest or a group of allied subjects). For too long deployment has been along functional lines, e.g., cataloging or acquisitions sections. Rather than encouraging subject specialization among staff, it tends to make them general practitioners. How can a cataloger easily win the respect of his academic colleagues? If library staff are deployed along subject lines, they will become specialists in their own right, competent to assist scholars and students in their subject areas. Herein lies their valid claim to academic status.

Centralization should thus offer Nigerian university libraries an atmosphere in which to solve the problem of staff advancement. The current hierarchy of one librarian, one deputy, a few senior sublibrarians, several sublibrarians, and several assistant librarians makes advancement difficult. Within a centralized system, it would be possible and rational to have a director of library services and three deputy directors (one responsible for general collection development, one in charge of technical services, the third responsible for readers' services). The duties of these levels would be both intellectual and administrative. Subordinate to the deputy responsible for technical services 
should be acquisitions librarians and catalogers who are subject specialists. These in turn should be assisted by bibliographic searchers. The deputy in charge of readers' services would be assisted by reference librarians in different or allied subject areas. At this level also would be special collection librarians and faculty librarians. The deputy in charge of collection development should be responsible for evaluating the stock and for insuring its development along established lines.

Development of these additional posts would be dependent on the subjects in each university's curriculum, the number of faculty libraries, the size and growth rate of the collection, the number of special collections in the library, faculty and student enrollment numbers, and the size of the library staff. It is quite possible, using these cri- teria, that some of these additional posts may not be necessary in a particular university library.

\section{ConCLUSION}

Because of these compelling conditions, Nigerian university libraries have only one option: operational centralization. Where money is scarce, effective financial control can greatly stretch resources; the organizational framework that enables librarians to practice as specialists in their own right is of tremendous benefit to readers and enhances staff prestige; a service hierarchy with built-in guarantees of advancement eliminates frustration among staff; speed and ease of access to library materials are assured by the existence of a union catalog. All these benefits are offshoots of operational centralization.

\section{REFERENCES}

1. Maurice F. Tauber, "Centralization and Decentralization in Academic Libraries: A Symposium," College \& Research Libraries 22: 327 (Sept. 1961).

2. J. O. Dipeolu, "Administrative Problems, in
Academic Libraries, with Particular Reference to Nigeria," Unesco Bulletin for Libraries 24:301 (Nov.-Dec. 1970).

3. University of Nigeria, Nsukka, Calendar 1970-73, p.122. 